\title{
Factors Affecting Students' Career Choice In Accounting: The Case Of A Turkish University
}

Ali Uyar, Fatih University, Turkey

Ali Haydar Güngörmüş, Fatih University, Turkey

Cemil Kuzey, Fatih University, Turkey

\begin{abstract}
This study investigates the reasons that influence students' career choices in accounting. In order to determine these reasons, a questionnaire survey has been employed. The empirical findings can be divided into two categories. First, students who have a desire to work in accounting field assume that accounting field provides good job opportunities, and the field matches with their abilities and interests. Second, students who have no desire to work in the field of accounting assume that other fields provide wider job opportunities and are less stressful, tiring, and tedious. In addition, the association of the factors that play role in choosing or not choosing a career in accounting field with student performance in accounting course is investigated.
\end{abstract}

Keywords: Accounting; Accounting Education; Accounting Career; Performance

\section{INTRODUCTION}

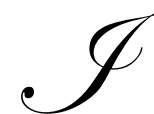

$\mathrm{n}$ recent years, the decline in quantity and quality of student enrollments in accounting majors alerted academicians, professionals, and professional bodies (Mauldin et al., 2000; Nelson, 1989; Adams et al., 1994; Glass and Oakley, 2003; Tan and Laswad, 2006; Smith, 2005; Chen et al., 2002; Garner and Dombrowski, 1997). This led researchers to investigate the reasons regarding career choice in accounting field.

Mauldin et al. (2000, p.142) state that the primary objective of accounting programs is to produce a sufficient number of graduates who possess substantial accounting knowledge, with the strong communication and analytical capabilities demanded by employers. In order to meet the demands of employers, accounting programs must graduate the best and brightest students with high aptitudes, but decreasing quantity and quality may mean the inability to meet the demands of the job market. Geiger and Ogilby (2000) emphasize the importance of the introductory accounting course, saying it is "a student's first and potentially only, exposure to accounting". Therefore, they state that the quality of the instructors' assignments during the course is important, in part, because it can impact the supply of accounting majors to both an accounting program and the accounting profession.

The purpose of this study is to investigate the factors why students choose or do not choose a career in accounting field. Furthermore, the paper examines the association of these factors with student performance in accounting course. The paper is divided into five parts. After this introductory first part, the second part provides a literature review about the subject. The third part explains the scope and methodology of the study. The fourth part presents the results of the study, and the last section provides concluding remarks.

\section{LITERATURE REVIEW}

Cohen and Hanno (1993) conducted a survey with 287 students who had either declared or intended to declare themselves as accounting majors and those who had either declared or intended to declare themselves as majors in a business field other than accounting (e.g. marketing, finance, general management, hotel management, 
economics). The results indicated that non-accounting majors may choose a major other than accounting because they believe accounting to be too number-oriented and boring. The students' choice of a major was consistent with their referenced opinions about majors. Success in introductory courses, skills and a background in math, as well as the workload in accounting courses were also identified as factors that facilitated or hindered choosing accounting as a major.

Mauldin et al. (2000) investigated students' choices of an accounting major. They found that the largest percentage of students chose accounting as their major during the first accounting course in college (41 percent), followed by selection during high school (34 percent). Among referents, the Accounting Principles instructor was the most influential one. The twelve factors that influenced the students' decisions included career opportunities, interest in the subject, instructor, money, parents, enjoyment, previous experience, life style offered because of the career, challenge, prestige, usefulness in operating a business, and other students.

Kim et al., (2002) conducted a study on business majors (e.g. accounting, finance, general business, management, marketing, MIS/CIS, and double major). They discovered that the top five reasons for choosing a major were: interest in a career associated with the major, good job opportunities, "good fit" with respondents" abilities, a desire to run a business some day, and projected earnings in the related career. The least selected reasons for choosing a major were the reputation of the major at the university, the perceived quality of instruction, the parents' influence, the amount and type of promotional information, and the influence of friends.

Yayla and Cengiz, (2005) determined five factors that play a role in choosing an accounting career. Those factors were "respondents' own choice", "family and close environment effect", "interesting profession", "earnings expectations", and "job opportunities".

Dinç (2008) utilized factor analysis and determined the following seven main factors in deciding career choice: high earnings expectations, career expectations, job experience, knowledge and ability, family environment, social status, and education environment.

Factors as recounted above about choosing a career in accounting field or not can be divided into two main groups: internal and external factors. Internal factors may include personal abilities, mathematical competency, interest in the field, etc. These factors do not depend on the students' geographical area. External factors, such as job opportunities, level of earnings a career offers, and the social status provided by the career are variable in various geographical areas. For example, while there are good job opportunities in one geographical area, another geographical area may not offer the same opportunities.

\section{SCOPE AND METHODOLOGY}

A number of researchers utilized a survey method for investigating the students' choices of accounting as major (Cohen and Hanno, 1993; Allen, 2004; Tan and Laswad, 2006; Dinç, 2008). The survey was applied only to the students who took an introductory financial accounting course. Introductory accounting courses which are taught in business majors are important in making decisions regarding students' both education and postgraduate lives (Güngörmüş and Uyar, 2010, p.444). In order to determine the students' career choices in relation to accounting, we conducted a survey of 320 students in business programs (e.g. accounting, foreign trade, banking, management, office management) who took the introductory financial accounting course in the two-year Istanbul Vocational School of Fatih University. Of the 320 students, 179 completed the questionnaire (55.94 percent). Course grades were obtained from the student information system. The range and mean for grades are $0-4$ and 1.94 respectively. Of the 179 respondents, 69 plan to work in the accounting field (38.5 percent), and 110 plan to work in a nonaccounting field. The distribution of students participating in the survey is presented in Table 1. 
Table 1: Descriptive Statistics

\begin{tabular}{|c|c|c|c|c|}
\hline \multicolumn{5}{|c|}{ Accounting grade } \\
\hline & Minimum & Maximum & Mean & Std. Deviation \\
\hline Accounting grade & 0.0 & 4.0 & 1.94 & 1.39 \\
\hline \multicolumn{5}{|c|}{ Do you plan to work in accounting field after graduation? } \\
\hline & \multicolumn{2}{|c|}{ Frequency } & \multicolumn{2}{|c|}{ Percent } \\
\hline Yes & \multicolumn{2}{|c|}{69} & \multicolumn{2}{|c|}{38.5} \\
\hline No & \multicolumn{2}{|c|}{110} & \multicolumn{2}{|c|}{61.5} \\
\hline Total & \multicolumn{2}{|c|}{179} & \multicolumn{2}{|c|}{100.0} \\
\hline \multicolumn{5}{|l|}{ Participants } \\
\hline Major & \multicolumn{2}{|c|}{ Frequency } & \multicolumn{2}{|c|}{ Percent } \\
\hline Banking & \multicolumn{2}{|c|}{11} & \multicolumn{2}{|c|}{6.1} \\
\hline Office Management & \multicolumn{2}{|c|}{10} & \multicolumn{2}{|c|}{5.6} \\
\hline Foreign Trade & \multicolumn{2}{|c|}{53} & \multicolumn{2}{|c|}{29.6} \\
\hline Management & \multicolumn{2}{|c|}{70} & \multicolumn{2}{|c|}{39.1} \\
\hline Accounting & \multicolumn{2}{|c|}{35} & \multicolumn{2}{|c|}{19.6} \\
\hline Total & \multicolumn{2}{|c|}{179} & \multicolumn{2}{|c|}{100.0} \\
\hline
\end{tabular}

\section{RESULTS AND DISCUSSION}

\section{Reasons for Choosing or Not Choosing a Career in Accounting Field}

In the survey, the question of "do you plan to work in the accounting field?" was asked. 69 out of 179 students answered "yes" to this question. If they answered "yes", the question "why do you plan to work in the accounting field?" was asked. Nine potential factors were provided to the respondents (Table 2) based on prior studies (Cohen and Hanno, 1993; Hermanson and Hermanson, 1995; Adams et al., 1994; Allen, 2004; Mauldin et al., 2000; Wooten, 1998; Tan and Laswad, 2006). Among the reasons, good job opportunities (50.72 percent), interest in accounting field (46.38 percent), good fit with respondent abilities (33.33 percent), suitability for independent working (24.64), and family influence (23.19) had the highest percentages. However, the desire to run a business some day (20.29 percent), expectations of high earnings (18.84 percent), the social status offered by the chosen career (10.14 percent), and the influence of friends and relatives (2.90 percent) were the lowest reasons selected for choosing a career in accounting. The findings confirm Kim et al., (2002) in some part, who found the three top reasons for choosing an accounting major were interest in a career associated with the major, good job opportunities, and "good fit" with the respondents' abilities. In both studies, the influence of friends was the least selected reason. On the other hand, in this study, the influence of parents had a higher percentage than in the study of Kim et al. (2002). These findings are also parallel to the findings of Mauldin et al. (2000) in part. For example, career opportunity, interest in the subject, and the influence of parents were among the top five reasons as in this study. However, money is not a factor within the top five reasons in this study, contrary to Mauldin et al. (2000). Life style or status that the job offers is not chosen within the top five reasons in both studies.

Those who answered "no" to the question of "do you plan to work in the accounting field?" were asked for their reasons (Table 3). Eight potential reasons were provided to the respondents based on prior studies (Tan and Laswad, 2006; Allen, 2004; Glass and Oakley, 2003; Cohen and Hanno, 1993). Among the choices, other fields offer wider job opportunities (48.18 percent), stressful and tiring profession (40 percent), boring nature of accounting profession (32.73 percent), and other fields offer higher earnings (32.73 percent) were the highest selections. The lowest rated reasons were difficulty of the career (26.36 percent), weakness in respondent's numerical abilities (21.82 percent), being a long process to become an accountant (15.45 percent), and legal responsibilities (4.55 percent). These results confirm Cohen and Hanno (1993) who comments that non-accounting majors may choose to stay away from accounting because they perceive that accounting is too number-oriented and boring. The results also support the view that the "unappealing nature (image) of accounting deters non-accounting majors from choosing accounting as a major" (Allen, 2004). The results also confirm Allen (2004), whose study of non-accounting majors indicates that "job opportunities" is the most influential factor for selecting a major. 
Table 2: Students' Reasons For Choosing Accounting As A Career ( $\mathrm{N}=69)$

\begin{tabular}{|l|c|c|}
\hline \multicolumn{1}{|c|}{ Reason } & Frequency & Percent* \\
\hline Good job opportunities (Opportunities) & 35 & 50.72 \\
\hline Interest in accounting field (Interest) & 32 & 46.38 \\
\hline Good fit with respondent abilities (Abilities) & 23 & 33.33 \\
\hline Suitability for independent working (Independent) & 17 & 24.64 \\
\hline Family influence (Family) & 16 & 23.19 \\
\hline Desire to run a business some day (Business) & 14 & 20.29 \\
\hline High earnings expectations (Earnings) & 13 & 18.84 \\
\hline Social status offered by career (Status) & 7 & 10.14 \\
\hline Effect of friends and relatives (Relatives) & 2 & 2.90 \\
\hline
\end{tabular}

* The total is greater than $\% 100$, because of multiple selection

Table 3: Students' Reasons for Not Choosing Accounting As A Career $(\mathrm{N}=110)$

\begin{tabular}{|l|c|c|}
\hline \multicolumn{1}{|c|}{ Reason } & Frequency & Percent* \\
\hline Other fields offer wider job opportunities (Other fields' opportunities) & 53 & 48.18 \\
\hline Stressful and tiring profession (Stressful) & 44 & 40.00 \\
\hline Accounting profession is boring (Boring) & 36 & 32.73 \\
\hline Other fields offer higher earnings (Other fields' earnings) & 36 & 32.73 \\
\hline Difficulty of the career (Difficulty) & 29 & 26.36 \\
\hline Weakness in numerical abilities (Numerical inabilities) & 24 & 21.82 \\
\hline It takes a long time to become accountant (Time) & 17 & 15.45 \\
\hline Legal responsibilities (Responsibility) & 5 & 4.55 \\
\hline
\end{tabular}

* The total is greater than $\% 100$, because of multiple selection

\section{Correlation Analysis}

In order to investigate whether there is a significant correlation between success in the accounting course and the nine reasons cited in the previous section for choosing a career in accounting field, the Pearson correlation analysis has been conducted (Table 4). The findings indicated a significant positive association between student success in the accounting course and the following variables:

- $\quad$ interest $(\mathrm{p}<0.01)$

- $\quad$ opportunities $(\mathrm{p}<0.01)$

- $\quad$ abilities $(\mathrm{p}<0.01)$

Furthermore, we investigated whether there is a significant correlation between success in the accounting course and the eight reasons cited in the previous section for not choosing a career in accounting field (Table 5). The results indicated a significant negative association between student success in the accounting course and the following variables:

- $\quad$ difficulty $(\mathrm{p}<0.01)$

- $\quad$ stressful $(\mathrm{p}<0.05)$

- $\quad$ other fields' earnings $(\mathrm{p}<0.05)$

- $\quad$ numerical inabilities $(\mathrm{p}<0.01)$ 
Table 4: The Pearson Correlation Analysis for Choosing a Career in Accounting ( $N=69)$

\begin{tabular}{|c|c|c|c|c|c|c|c|c|c|c|}
\hline & $\begin{array}{c}\text { Accounting } \\
\text { Grade }\end{array}$ & Interest & Opportunities & Abilities & Independent & Business & Earnings & Status & Family & Relatives \\
\hline Accounting grade & 1.000 & $0.236 * *$ & $0.230 * *$ & $0.221 * *$ & 0.117 & 0.110 & 0.097 & -0.096 & 0.112 & 0.101 \\
\hline Interest & $0.236 * *$ & 1.000 & $0.285 * *$ & $0.562 * *$ & $0.147 *$ & 0.081 & $0.263 * *$ & $0.207 * *$ & $0.160 *$ & 0.089 \\
\hline Opportunities & $0.230 * *$ & $0.285 * *$ & 1.000 & $0.232 * *$ & $0.225 * *$ & 0.119 & $0.351 * *$ & $0.191 *$ & $0.241 * *$ & 0.082 \\
\hline Abilities & $0.221 * *$ & $0.562 * *$ & $0.232 * *$ & 1.000 & $0.160 *$ & 0.137 & $0.214 * *$ & 0.009 & 0.055 & 0.118 \\
\hline Independent & 0.117 & $0.147 *$ & $0.225 * *$ & $0.160 *$ & 1.000 & -0.023 & -0.017 & 0.033 & $0.232 * *$ & -0.034 \\
\hline Business & 0.110 & 0.081 & 0.119 & 0.137 & -0.023 & 1.000 & 0.079 & 0.049 & 0.128 & $0.167^{*}$ \\
\hline \begin{tabular}{|l|} 
Earnings \\
\end{tabular} & 0.097 & $0.263 * *$ & $0.351 * *$ & $0.214 * *$ & -0.017 & 0.079 & 1.000 & $0.166^{*}$ & $0.290 * *$ & $0.175^{*}$ \\
\hline Status & -0.096 & $0.207 * *$ & $0.191 *$ & 0.009 & 0.033 & 0.049 & $0.166^{*}$ & 1.000 & $0.240 * *$ & -0.021 \\
\hline \begin{tabular}{|l|} 
Family \\
\end{tabular} & 0.112 & $0.160^{*}$ & $0.241 * *$ & 0.055 & $0.232 * *$ & 0.128 & $0.290 * *$ & $0.240 * *$ & 1.000 & $0.153^{*}$ \\
\hline Relatives & 0.101 & 0.089 & 0.082 & 0.118 & -0.034 & $0.167^{*}$ & $0.175^{*}$ & $\begin{array}{l}-0.021 \\
\end{array}$ & $0.153 *$ & 1.000 \\
\hline
\end{tabular}

** Correlation is significant at the 0.01 level (2-tailed); * Correlation is significant at the 0.05 level (2-tailed).

Table 5: The Pearson Correlation Analysis for Not Choosing a Career in Accounting ( $N=110$

\begin{tabular}{|c|c|c|c|c|c|c|c|c|c|}
\hline & $\begin{array}{c}\text { Accounting } \\
\text { Grade }\end{array}$ & Difficulty & Time & Boring & Stressful & Responsibility & $\begin{array}{l}\text { Other Fields' } \\
\text { Opportunities }\end{array}$ & $\begin{array}{c}\text { Other Fields' } \\
\text { Earnings }\end{array}$ & $\begin{array}{l}\text { Numerical } \\
\text { Inabilities }\end{array}$ \\
\hline Accounting grade & 1.000 & $-0.294 * *$ & 0.000 & -0.120 & $-0.182 *$ & -0.128 & -0.030 & $-0.175 *$ & $-0.262 * *$ \\
\hline Difficulty & $-0.294 * *$ & 1.000 & 0.064 & $0.158 *$ & $0.242 * *$ & 0.109 & -0.019 & -0.031 & $0.227 * *$ \\
\hline Time & 0.000 & 0.064 & 1.000 & 0.123 & $0.346 * *$ & -0.055 & -0.001 & 0.028 & -0.016 \\
\hline Boring & -0.120 & $0.158 *$ & 0.123 & 1.000 & $0.296 * *$ & 0.084 & 0.102 & 0.061 & 0.007 \\
\hline Stressful & $-0.182 *$ & $0.242 * *$ & $0.346 * *$ & $0.296 * *$ & 1.000 & -0.018 & 0.084 & 0.070 & -0.034 \\
\hline Responsibility & -0.128 & 0.109 & -0.055 & 0.084 & -0.018 & 1.000 & $0.187 *$ & $0.253 * *$ & 0.033 \\
\hline Other fields' opportunities & -0.030 & -0.019 & -0.001 & 0.102 & 0.084 & $0.187 *$ & 1.000 & $0.438 * *$ & 0.032 \\
\hline Other fields' earnings & $-0.175^{*}$ & -0.031 & 0.028 & 0.061 & 0.070 & $0.253 * *$ & $0.438 * *$ & 1.000 & 0.089 \\
\hline Numerical inabilities & $-0.262 * *$ & $0.227 * *$ & -0.016 & 0.007 & -0.034 & 0.033 & 0.032 & 0.089 & 1.000 \\
\hline
\end{tabular}

** Correlation is significant at the 0.01 level (2-tailed); * Correlation is significant at the 0.05 level (2-tailed). 


\section{Regression Analysis}

In order to investigate the association between performance in accounting courses and the factors that play a role in deciding whether or not to choose accounting field, we use stepwise regression. The data was analyzed using SPSS Statistical program. We established two separate regression models. In both models, the dependent variable $(\mathrm{Y})$ is the accounting course performance.

\section{First model: Accounting is not a career choice}

The first model involves the association between performance in an accounting course and the factors that play a role in not choosing the accounting field as a career choice. In the model, the explanatory variables are as follows: difficulty $\left(\mathrm{X}_{1}\right)$, time $\left(\mathrm{X}_{2}\right)$, boredom $\left(\mathrm{X}_{3}\right)$, stressful $\left(\mathrm{X}_{4}\right)$, responsibility $\left(\mathrm{X}_{5}\right)$, other areas' opportunities $\left(\mathrm{X}_{6}\right)$, other areas' earnings $\left(\mathrm{X}_{7}\right)$, and numerical abilities $\left(\mathrm{X}_{8}\right)$. The best fitting linear regression model that explains the association between performance in the accounting course and the factors that play a role in not choosing the accounting field as a career choice is as follows:

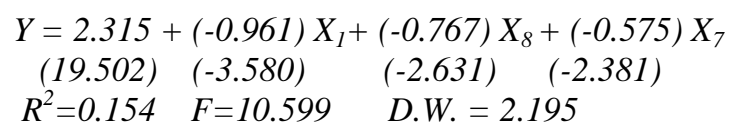

The optimal model is calculated by excluding those that are not significant at a $5 \%$ significance level. According to the model above, difficulty $\left(\mathrm{X}_{1}\right)$, numerical abilities $\left(\mathrm{X}_{8}\right)$ and other areas' earnings $\left(\mathrm{X}_{7}\right)$ are ranked respectively in the order of importance to denote factors that affect accounting performance significantly. The results of the regression indicated that these predictors explained $15.4 \%$ of the variance $\left(R^{2}=0.154, F(3,175)\right.$ $=10.599, p<0.01)$. It was discovered that difficulty $(\beta=-0.256, p<0.001)$, numerical abilities $(\beta=-0.189, p<0.01)$ and other areas' earnings $(\beta=-0.166, \mathrm{p}<0.05)$ significantly predicted accounting performance.

As the results of stepwise regression show, the relationships between difficulty of the career $\left(\mathrm{X}_{1}\right)$, weakness in respondent's numerical abilities $\left(\mathrm{X}_{8}\right)$, other areas offer higher earnings $\left(\mathrm{X}_{7}\right)$ and accounting course performance (Y) are obvious. Variables such as taking a long time to become accountant (Time), accounting profession is boring (Boredom), stressful and tiring profession (Stressful), legal responsibilities (Responsibilities) and other areas offer wider job opportunities (Other areas' opportunities) are excluded in our model.

\section{Second model: Accounting is a career choice}

The second model concerns the association between performance in the accounting course and the factors that play a role in choosing the accounting field as a career choice. In this case, the variables that affect a student's career choice to be an accountant are as follows: good job opportunities $\left(\mathrm{X}_{9}\right)$, interest in the accounting area $\left(\mathrm{X}_{10}\right)$, good fit with respondent's abilities $\left(\mathrm{X}_{11}\right)$, suitability for independent working $\left(\mathrm{X}_{12}\right)$, family effect $\left(\mathrm{X}_{13}\right)$, desire to run a business some day $\left(\mathrm{X}_{14}\right)$, high earnings expectations $\left(\mathrm{X}_{15}\right)$, social status that this career offers $\left(\mathrm{X}_{16}\right)$, and the influence of my friends and relatives $\left(\mathrm{X}_{17}\right)$. The best fitting model to detect the relationship between the given explanatory variables above, as well as the accounting performance $(\mathrm{Y})$ is as follows:

$$
\begin{array}{cccc}
Y=1.714+0.777 X_{10}+0.707 X_{9}+(-1.276) X_{16} \\
(14.924) & (2.861) & (2.702) & (-2.435) \\
R^{2}=0.114 & F=7.531 & \text { D.W. }=2.184
\end{array}
$$

Interest in the accounting area $(\beta=0.215, \mathrm{p}<0.01)$, good job opportunities $(\beta=0.203, \mathrm{p}<0.01)$ and social status that the career offers $(\beta=-0.179, \mathrm{p}<0.05)$ significantly predict the students performance in the accounting course. Our optimal model excludes the non-significant variables at the 5\% significant level. The stepwise regression results also shows that predictor variables explain $11.4 \%$ of the variance $\left(R^{2}=0.114, F(3,175)=7.531\right.$, $\mathrm{p}<0.01)$. 


\section{CONCLUSION}

The correlation analysis indicated that three factors that play role in career choice in accounting field have a positive significant association with student success in the accounting course. These factors are "interest in accounting", "perceived job opportunities", and "suitability of abilities". Firstly, if the students are interested in a field, they are more likely to be successful in that field because interest in a field may produce high motivation. The opposite of this may also be true. Success in a field may trigger interest. Hence, there is a two-sided relationship. Secondly, the students' perceptions regarding job opportunities may influence their field selection. The wider the field offers job opportunities, the more likely students choose that field. Thirdly, suitability of abilities is also a major influence on student success, especially in numerical courses. Therefore, the more closely a student's abilities relate to a field, the more likely he or she will be successful in that field.

Furthermore, a significant negative association was found between student success in accounting course and the factors of the perceived "difficulty of accounting", "stressful nature of accounting field", the expectations of "higher earnings in other fields", and "inadequate numerical abilities" of students. The students who perceive accounting field difficult are likely to be unsuccessful, because their perception plays a discouraging role. The stressful nature of the accounting profession is another important factor that deters students from choosing this field. Depending on the geographical area, non-accounting professions may offer higher earnings than the accounting profession. This may also play a negative role in choosing an accounting career. The lack of numerical abilities is another daunting factor because the accounting field requires an accountant to have numerical abilities when preparing financial statements, analyzing them, etc. Therefore, the students who lack such capabilities are likely to be unsuccessful in accounting and this may contribute to declining numbers of students selecting an accounting career.

Our established regression models provide valuable insights to show the associations between accounting course performance and the significant factors that play a role in deciding whether or not to choose accounting as a career. The first model proved that perceived "difficulty in accounting course", "lack of numerical abilities", and "earnings opportunities in other fields" have a significant negative association with performance in the accounting course.

Furthermore, the second model indicated that "interest in the accounting field" and perceived "job opportunities in the accounting field" have significant positive associations with success in the accounting course. On the other hand, the factor of "social status" that accounting career offers has a significant negative association with course performance. This may be due to the fact that choosing the accounting field because of social status does not automatically mean that a student will be successful in that field.

There are some implications of the study. Educators can arrange supportive activities for those who do not plan to work in the accounting field due to perceived difficulty of the field. Secondly, accounting departments could invite professionals to give conferences about job opportunities in this field, and encourage and motivate students by giving real life examples and relating success stories. In addition, the universities may build a bridge between education and work life by creating good relationships with the business world.

This study was conducted in five separate business programs of a single university. To generalize the results, these findings need to be tested in a wider sample, which includes several universities. The factors that play a role in career choice may not be limited to those, which were used in this study. The extent of these factors may be widened in further studies.

\section{ACKNOWLEDGEMENT}

We would like to thank Assist. Prof. Gökhan Torlak for his help in editing this paper, and his guidance during the publication process. 


\section{AUTHOR INFORMATION}

Ali Uyar is an Associate Professor of Accounting and Finance in the Department of Business Administration at Fatih University in Istanbul, Turkey. He received his $\mathrm{PhD}$ in Accounting and Finance from Marmara University, Turkey. He teaches cost accounting, managerial accounting, and financial accounting. His research interests are related to cost and management accounting practices, corporate reporting, and voluntary disclosure. His research papers have been published in various national and international journals. E-mail: aliuyar@hotmail.com

Ali Haydar Güngörmüş is currently pursuing a $\mathrm{PhD}$ in Accounting. He lectures, at the same time, financial accounting and other accounting courses in Vocational School of Fatih University, Turkey. He is CPA and has private sector experience in accounting field. His research interests are related to financial accounting, corporate reporting, and Turkish Uniform Chart of Accounts. His research papers have been published in various national and international journals. E-mail: ahgungor@fatih.edu.tr

Cemil Kuzey lectures at the Department of Management at Fatih University in Istanbul, Turkey, teaching Operation Research and Statistics for Social Sciences. He is currently working towards acquiring a Ph.D. degree in Business Administration through the Department of Quantitative Analysis, Istanbul University, Turkey. Among his academic pursuits, he took several graduate courses at the Ontario Institute for Studies in Education, University of Toronto. His research interests are related to Operation Research, Data Mining, and Business Intelligence. E-mail: ckuzey@fatih.edu.tr

\section{REFERENCES}

1. Adams, S.J., Pryor, L.J. and Adams, S.L. (1994), "Attraction and retention of high-aptitude students in accounting: An exploratory longitudinal study", Issues in Accounting Education, 9(1), pp. 45-58.

2. Allen, C.L. (2004), "Business students' perception of the image of accounting”, Managerial Auditing Journal, 19(2), pp. 235-258.

3. Chen, C., Jones, K.T. and McIntyre, D.D. (2002), "Will Enron deter students from majoring in accounting?", The CPA Journal, 72(12), pp. 13-15.

4. Cohen, J. and Hanno, D.M. (1993), "An analysis of underlying constructs affecting the choice of accounting as a major", Issues in Accounting Education, 8(2), pp. 219-238.

5. Dinç, E. (2008), "Meslek Seçiminde Etkili Faktörlerin İncelenmesi: Meslek Yüksek Okulu- Muhasebe Programı Ögrencileri Üzerine Bir Araştırma”, Kocaeli Üniversitesi Sosyal Bilimler Enstitüsü Dergisi, 16, pp. $90-106$

6. Garner, R.M. and Dombrowski, R.F. (1997), "Recruiting the "best and the brightest": the role of university accounting programs and state CPA societies", Issues in Accounting Education, 12(2), pp. 299-314.

7. Geiger, M.A. and Ogilby, S.M. (2000), "The first course in accounting: student's perceptions and their effect on the decision to major in accounting", Journal of Accounting Education, 18, pp. 63-78.

8. Glass, J.C. and Oakley, B. (2003), "Attrition and retention among accounting majors in community colleges: problems and possible remediation”, Community College Journal of Research and Practice, 27, pp. 679-698.

9. Güngörmüş̧, A.H. and Uyar, A. (2010), “Comparison of Accounting and Other Program Students' Performances in Introductory Accounting Course", Suleyman Demirel University, The Journal of Faculty of Economics and Administrative Sciences, Vol. 15, No. 2, pp. 443-453.

10. Hermanson, D. R. and Hermanson, R. H. (1995), "Are America's top businesses students steering clear of accounting?", Ohio CPA Journal, 54(2), pp. 26-30.

11. Kim, D., Markham, F.S. and Cangelosi, J.D. (2002), "Why students pursue the business degree: A comparison of business majors across universities", Journal of Education for Business, 78(1), pp. 28-32.

12. Mauldin, S., Crain, J.L. and Mounce, P.H. (2000), "The accounting principles instructor's influence on student's decision to major in accounting", Journal of Education for Business, 75(3), pp.142-148.

13. Nelson, A. (1989), "The human resource dilemma in accounting", Journal of Accountancy, 168(2), pp. 4652.

14. Smith, G. (2005), "Reversing the decreasing trend of students majoring in accounting", Managerial Auditing Journal, 20(9), pp. 936-944. 
15. Tan, L. M. and Laswad, F. (2006), "Students' beliefs, attitudes and intentions to major in accounting”, Accounting Education: an international journal, 15(2), pp. 167-187.

16. Wooten, T.C. (1998), "Factors influencing student learning in introductory accounting classes: a comparison of traditional and nontraditional students", Issues in Accounting Education, 13(2), pp. 357-373.

17. Yayla, H.E. ve Cengiz, E. (2005), "Muhasebe Mesleğinin Tercih Edilmesinde Etkili Olan Faktörlerin Belirlenmesine Yönelik Bir Alan Çalışması: Karadeniz Teknik Üniversitesi Örneği”, Muhasebe ve Denetime Bakış, Eylül, pp. 147-168. 


\section{NOTES}

